\title{
Effects of different hay: concentrate ratios on body and testicular- epididymal biometry and metabolic profile of Santa Ines lambs
}

\section{Efeito de diferentes proporções de volumoso: concentrado sobre a biometria testículo-epididimária e corporal e perfil metabólico de cordeiros Santa Inês}

\author{
Gabriel Cândido Bandeira ${ }^{1}$; Ana Cláudia Nascimento Campos ${ }^{2 *}$; \\ Elzania Sales Pereira²; Marco Antonio Basilio Linard'; \\ Karoliny Farias Castelo-Branco ${ }^{1}$; Monalisa Eva Santos Evangelista ${ }^{1}$; \\ Dayanne Lima de Sousa ${ }^{1}$; Raisa Rodrigues Santos Rios ${ }^{3}$; \\ Assis Rubens Montenegro ${ }^{1}$; Carla Renata Figueiredo Gadelha ${ }^{2}$
}

\begin{abstract}
This study was carried out to verify the effects of different hay: concentrate ratios on body, testicular and epididymal development and metabolic profile of hair sheep lambs. Twenty-nine Santa Ines lambs were used. Treatments consisted of diets with different hay: concentrate ratios (100:0-Control, 80:20T1, 60:40-T2, 40:60-T3 and 20:80-T4). The characteristics evaluated were: body weight (BW), body condition score (BCS), hearth girth (HG), body length (BL), height at withers (HW), height at rump (HR), rump width (RW), chest width (CW), scrotal perimeter (SP), testis length (TL) testis width (TW), testis thickness (TT), cauda epididymal length (CEL), cauda epididymal width (CAW), cauda epididymal thickness (CET), scrotal skin thickness (SST) and testicular volume (TV). Blood samples were collected to analyze glucose, urea, albumin, total cholesterol, total proteins, inorganic phosphate and magnesium concentrations. The body and testicular-epididymal measurements increased linearly with increases in the energy concentration in the diet. BW, BL, CW, RW, HG and BCS showed positive high correlations ( $\mathrm{r}=0.71$ to 0.94$)$ with all testis-epididymal measurements. The results of the metabolic profile study showed interactions between the addition of the concentrated feed and time of blood collection on total proteins, albumin, urea, cholesterol, phosphorus and magnesium concentrations. At the beginning of the trial, hypoproteinemia and hypoalbuminemia were verified in T3 and T4. However, the indices returned to normal over time with the continuity in the diet supplied. Hypomagnesaemia was verified in all treatments. The plasmatic phosphorus concentration was sufficiently high at the end of all treatments, except control. In conclusion, the BL, HG, CW, RW as well as the BCS may be used to estimate the development of the testes and epididymis. The metabolic profile results verified that adjusts are necessary in the amount of concentrated feed given to the lambs when Tifton 85 hay (Cynodon spp) is provided to the animals.
\end{abstract}

Key words: Albumin. Body condition score. Body weight. Minerals. Sheep. Withers height.

\footnotetext{
${ }^{1}$ Discentes do Programa de Pós-Graduação em Zootecnia, UFC, Fortaleza, CE, Brasil. E-mail: gabrieligt@gmail.com; marcoantoniozoo@hotmail.com; karolinyfarias@gmail.com; monalisaeva@hotmail.com; dayannels@hotmail.com; assismontenegro@yahoo.com.br

2 Prof $^{\text {as }}$ Dr $^{\text {as }}$, Pesquisadoras, Dept ${ }^{\circ}$ Zootecnia, UFC, Fortaleza, CE, Brasil. E-mail: acncampos11@gmail.com; elzania@hotmail. com; crgadelha@yahoo.com

${ }^{3}$ Discente do Programa de Pós-Graduação em Ciencias Veterinárias, UECE, Fortaleza, CE, Brasil. E-mail: raisa.rios@hotmail.com

* Author for correspondence
} 


\section{Resumo}

Este estudo objetivou verificar os efeitos de diferentes proporções de feno: concentrado sobre o desenvolvimento corporal, testicular e epididimário, bem como, sobre perfil metabólico de cordeiros deslanados. Foram utilizados vinte e nove cordeiros Santa Inês. Os tratamentos foram constituídos de dietas com diferentes proporções de feno: concentrado (100: 0- Controle; 80: 20- T1, 60: 40- T2, 40: 60T3 e 20: 80- T4). As características avaliadas foram: peso corporal (PC), escore de condição corporal (ECC), perímetro torácico (PT), comprimento do corpo (CC), altura na cernelha (AC), altura na garupa (AG), largura da garupa (LG), largura do peito (LP), perímetro escrotal (PS), comprimento do testículo (CT) largura dos testículos (LT), espessura de testículo (ET), comprimento da cauda do epidídimo (CCE), a largura da cauda do epidídimo (LCE), espessura da cauda do epidídimo (ECE), espessura da pele escrotal (EPE) e volume testicular (VT). Amostras de sangue foram colhidas para análise de glicose, ureia, albumina, colesterol total, proteínas totais, fosfato e magnésio. A biometria corporal, testicular e epididimárias aumentaram linearmente com o aumento da proporção de concentrado na dieta. PC, CC, LP, AC, PT e ECC mostraram correlação alta e positiva $(r=0,71-0,94)$, com todas as medidas testículoepidídimárias. Os resultados do estudo mostraram interação entre o perfil metabólico, os tratamentos e o momento da coleta para as concentrações de proteínas totais, albumina, ureia, colesterol, fósforo e magnésio concentrado. No início do experimento foram verificadas hipoproteinemia e hipoalbuminemia em T3 e T4. No entanto, os índices voltaram ao normal com a continuidade do fornecimento da dieta. Hipomagnesemia foi verificada em todos os tratamentos. A concentração plasmática de fósforo foi significativamente alta no fim de todos os tratamentos, com exceção de controle. As medidas comprimento do corpo, perímetro torácico, largura de peito, altura de cernelha e o escore de condição corporal podem ser usados para estimar o desenvolvimento dos testículos e epidídimo. O resultado do perfil metabólico permitiu verificar que são necessários ajustes na quantidade de ração concentrada administrada aos cordeiros quando feno de tifton 85 (Cynodon spp) é fornecido aos animais.

Palavras-chave: Albumina. Escore de condição corporal. Minerais. Ovinos. Peso corporal. Perímetro torácico.

\section{Introduction}

According to Brazilian Institute for Geography and Statistics (IBGE) in 2011, there are approximately 17,662,201 sheep in Brazil and around of 9,566,968 sheep only in northeastern region of Brazil. Hair sheep represent 60 to $70 \%$ of the Brazilian sheep population. An example is the Santa Ines, an important native breed of hair sheep in northeastern Brazil, used for meat and skin production and highly valued on the international market (PAIVA et al., 2005).

Some studies have shown that climatic and nutritional variations can cause changes in body composition (BABINSZKY et al., 2011), body and genital biometry (YADAV et al., 2013) and metabolic profile (ABARGHANI et al., 2013). Biometrical measurements have been used to evaluate the characteristics of animals that may vary due to the influence of breed evolution, environment and nutrition age and live weight (OWENS et al., 1993).

Patterns of development are useful in assessing conformation. These body measurements have been used at various times for the estimation of weight (YILMAZ et al., 2013), breed characterization and differentiation (YAKUBU; IBRAHIM, 2011), and for early selection of ram lambs (ELMAZ et al., 2007). As regards testicular-epididymal biometry, some studies have demonstrated that body weight may be reflected in testicle size (DUGUMA et al., 2002), because the heritability between scrotal circumference and testis diameter is moderate to high. Early studies found that rams with the largest testicular measurements had higher fertility in ewes, which might lead to improved fertility of the population and, consequently, reduce the number of breeding rams required (ABBASI; GHAFOURI-KESBI, 2011).

The blood biochemistry composition may reflect the metabolic condition in an animal's 
tissue (GONZÁLEZ; SCHEFFER, 2003) and may be a valuable diagnostic tool that can be used to evaluate several body systems (RUSSELL; ROUSSELL, 2007), diagnose metabolic disorders (GATTANI et al., 2011), and assess an animal's adaptation to nutritional and physiological challenges (DAVID et al., 2012). Moreover, it provides insight into maximizing reproductive potential and the profitability of the production system, and also to designing nutritional strategies.

This study was carried out to verify the effects of different hay: concentrate ratios on biometric development (body, testicular and epididymal) and the metabolic profile of intensively managed hair sheep lamb in Northeast Brazil.

\section{Material and Methods}

\section{Animals and experimental diets}

Humane animal care and handling procedures were followed according to the University's animal care committee. The experiment was conducted in the Department of Animal Science of the Federal University of Ceara, in Fortaleza, CE, Brazil, from March to June 2011. Twenty-nine non-castrated Santa Ines lambs, with an initial average BW of $14.77 \pm 1.26 \mathrm{~kg}$ and approximately two-months old were used. First, the animals were identified, dewormed and placed in individual stalls with feeding troughs to supply the diets and water. The lambs were allocated randomly to five treatments that consisted of different hay: concentrate ratios (100:0 - control, 80:20 - T1, 60:40 - T2, 40:60 T3, and 20:80 - T4) with five lambs each. However one lamb died in middle of experiment. The experimental diets were formulated according to the NRC (2007) to promote daily gains of $200 \mathrm{~g}$, except for the first treatment, which aimed only to meet maintenance requirements. The ingredients and chemical compositions of the experimental diets are shown in Table 1.

Table 1. Composition of the experimental diets.

\begin{tabular}{lccccc}
\hline \multirow{2}{*}{ Ingredients (g/kg NM) } & \multicolumn{3}{c}{ Levels of Metabolizable Energy (Mcal/kg DM) } \\
\cline { 2 - 6 } & $1.13($ Control) & $1.40(\mathrm{~T} 1)$ & $1.73(\mathrm{~T} 2)$ & $2.22(\mathrm{~T} 3)$ & $2.60(\mathrm{~T} 4)$ \\
\hline Tifton-85 (Cynodon sp.) & 1000.0 & 800.0 & 600.0 & 400.0 & 200.0 \\
Concentrate & - & 200.0 & 400.0 & 600.0 & 800.0 \\
Ground Corn & - & 158.7 & 694.5 & 724.6 & 756.1 \\
Soybean meal & - & 806.5 & 285.3 & 248.8 & 225.9 \\
Urea & - & 30.0 & 12.5 & 11.2 & 5.1 \\
Limestone & - & - & - & 5.4 & 6.6 \\
Dicalcium phosphate & - & - & - & - & 0.7 \\
Sodium chloride & - & 4.0 & 7.0 & 9.3 & 5.0 \\
Mineral premix & - & 0.8 & 0.7 & 0.7 & 0.6 \\
\hline Chemical composition $(\mathrm{g} / \mathrm{kg} \mathrm{DM})$ & & & & & \\
\hline Dry matter & 920.0 & 911.3 & 903.8 & 897.3 & 894.8 \\
Crude protein & 95.4 & 161.2 & 161.6 & 162.9 & 163.7 \\
Ether extract & 18.5 & 17.5 & 23.8 & 24.1 & 30.9 \\
Ash & 56.2 & 57.3 & 58.4 & 45.7 & 39.0 \\
Neutral detergent fiber & 734.5 & 618.1 & 499.5 & 382.1 & 264.6 \\
Acid detergent fiber & 364.3 & 305.5 & 236.3 & 175.5 & 112.4 \\
NDFap & 668.3 & 562.0 & 453.6 & 348.3 & 237.5 \\
\hline
\end{tabular}




\begin{tabular}{lccccc} 
& \multicolumn{3}{c}{... Continuation } \\
\hline Non-fibrous carbohydrate & 161.6 & 212.8 & 323.1 & 431.2 & 536.2 \\
Total digestible nutrients & 312.7 & 387.3 & 479.5 & 615.4 & 718.3 \\
TDN:CP & 3.28 & 2.40 & 2.97 & 3.78 & 4.39 \\
\hline
\end{tabular}

${ }^{a}$ Composition: Ca 7.5\%; P 3\%; Fe 16500 ppm; Mn 9750 ppm; Zn 35000 ppm; I 1000 ppm; Se 225 ppm; Co 1000 ppm; beutral detergent fiber corrected for ash and protein; ${ }^{\circ}$ Total digestible nutrients:crude protein.

\section{Management description, body and genital} measurements

The diets were provided twice per day, at 8 a.m. and 4 p.m., being adjusted daily to allow approximately $20 \%$ leftovers based on the previous day's intake. A 14-day adaptation period was used to adapt the lambs to the diets. The experiment lasted 42 days.

The characteristics evaluated weekly included body condition score (BCS) according to Russel et al. (1969). Body weights (BW) of the lambs were measured by a digital scale with a 50 -g sensitivity. The following measurements were made using a tape measure and a measurement stick: hearth girth (HG), measured as body circumference behind the scapula; body length (BL), measured as the distance between the point of shoulder and the pin bone; height at withers (HW), defined as the distance from the base of the hoof to the highest point of the withers; height at rump (HR), measured as the vertical distance from the top of the pelvic girdle to the ground; rump width (RW), measured as the distance between the coxal tubers and chest width (CW), the horizontally measured distance right behind the caput humeri.

Scrotal perimeter (SP) was measured at the widest point of the scrotum taken with a tape measure. The measurements of each left and right testis/epididymal included: testis length (TL), testis width (TW), testis thickness (TT), cauda epididymal length (CEL), cauda epididymal width (CAW), cauda epididymal thickness (CET) and scrotal skin thickness (SST), the latter measured with a caliper after forcing each testis and cauda epididymal against the scrotum.

Testicular volume was calculated as in previous studies using the formula for a cylinder, where $\mathrm{V}=2\left[\left(\mathrm{r}^{2}\right) \times \Pi \mathrm{x} \mathrm{h}\right]$, wherein: $\mathrm{r}=$ testis width $/ 2, \mathrm{~h}=$ testis length, and $\pi(\mathrm{Pi})=3.14$. The classification of the shape of a lamb's testicles (normal ovoid, long ovoid, or spheroid-shaped) was based on clinical observation and was then substantiated by calculation of length to width ratios. The length: width ratio of testicles defined as normal ovoid was approximately $1.6: 1$; a ratio greater than or equal to 1.9:1 was classified as a lamb having long ovoid testicles; and a ratio of less than or equal to 1.4:1 was classified as a lamb with spheroid-shaped testicles (BAILEY et al., 1996).

\section{Blood sampling for determination of metabolic profile}

Monthly and after adaptation, blood samples with anti-coagulant (heparin) were collected by jugular vein puncture. Samples were centrifuged at $350 \mathrm{~g} / 15 \mathrm{~min}$ and plasma was frozen at $-20^{\circ} \mathrm{C}$ until analyzed for glucose, urea, albumin, total cholesterol, total proteins, inorganic phosphate and magnesium concentrations. These constituents were assayed in duplicate using colorimetric commercial kits of the LABTEST ${ }^{\circledR}$ brand.

\section{Chemical analysis}

Concentrate, forage, total mixed rations (TMR) and refuse samples were dried in a forced air oven at $55^{\circ} \mathrm{C}$ for $72 \mathrm{~h}$ and then ground in a knife mill with a $1 \mathrm{~mm}$ screen (Wiley mill, Arthur H. Thomas, 
Philadelphia, PA, USA). The samples were analyzed to determine the contents of dry matter (DM, method number 930.15) (AOAC, 1990); ash, method number 924.05 (AOAC, 1990), crude protein (CP, method number 984.13) (AOAC, 1990); ether extract (EE, method number 920.39) (AOAC, 1990) and acid detergent fiber (ADF, method number 973.18) (AOAC, 1990). To analyze neutral detergent fiber (NDF), the samples were treated with thermostable alpha-amylase without using sodium sulfite and corrected for residual ash and nitrogenous compounds. The content of non-fibrous carbohydrates (NFC) was calculated according to Weiss (1999), where: $\mathrm{NFC}_{(\%)}=100-(\% \mathrm{NDFap}+$ $\% \mathrm{CP}+\% \mathrm{EE}+\% \mathrm{Ash})$. For the concentrate, due to the presence of urea in its constitution, the content of NFC was calculated according to Hall (2000), where: $\mathrm{NFC}_{(\%)}=100-[(\% \mathrm{CP}-\% \mathrm{CP}$ derived from urea $+\%$ Urea $)+\%$ NDFap $+\%$ EE $+\%$ Ash $]$. The content of total digestible nutrients (TDN) was calculated using the following equation: TDN = $\mathrm{CPd}+\mathrm{NFCd}+\mathrm{NDFapd}+(\mathrm{EEd} * 2.25)$, where CPd, NFCd, NDFapd and EEd corresponded to digestible crude protein, digestible non-fibrous carbohydrates, digestible neutral detergent fiber corrected for ash and protein and digestible ether extract, respectively (WEISS, 1999).

\section{Statistical analyses}

The blood dates were evaluated in a completely randomized design using a split plot scheme with treatment as the main plot and sampling time as the subplot. We calculated the means and standard deviations (SD) of the parameters glucose, urea, albumin, total cholesterol, total proteins, magnesium and inorganic phosphate concentrations. When significant effects were detected the means were compared by the Tukey test with $5 \%$ error probability.
Biometric parameters were evaluated by analysis of variance (PROC GLM) and regression (PROC REG). The statistical analyses were performed using SAS version 9.1 (SAS, 2003). The Pearson correlation coefficient was used to evaluate the degree of association of the body and testicularepididymal measurements.

\section{Results and Discussion}

The body and testicular-epididymal measurements increased linearly with increases in the energy concentration in the diet (Table 2). Energy is a dietary element that is responsible for differential utilization of nutrients and thereby affects the productivity and gain of an animal (NRC, 2007). Increasing the energetic density had a positive influence on the lambs' measured biometrics. These results were similar to found by Muhammad and Tukur (2013); however, they were different from those verified by Atta and El Khidir (2004), who did not find a positive effect on body measurements, but the diets the authors supplied were iso-nitrogenous and had the same energy values. In this regard, they were different from the diets used in the current study, because we supplied increased energy diets.

With regard to testicular shape, a predominance of long ovoid testicles was observed until 74 days. However, by the time of the 88 days old, the frequency distribution between normal ovoid and long ovoid testicles was similar (Table 3). However, a long ovoid testicular shape is predominant from 3 to 6 months old, and only from 8 months old are long ovoid testicles predominant (LOUVANDINI et al., 2008). Early studies showed that a high-energy level in the diet accelerates testicular development in lambs; moreover, changes in testicle shape may prejudice a possible genetic evaluation based only on scrotal perimeter. 
Table 2. Body and testicle-epididimis measurements of the hair sheep lamb submitted at different hay: concentrate ratios.

\begin{tabular}{|c|c|c|c|c|c|c|c|c|c|}
\hline \multirow[b]{2}{*}{ Parameters } & \multicolumn{5}{|c|}{ Hay: concentrate ratios } & \multirow[b]{2}{*}{$\mathrm{r} 2$} & \multirow[b]{2}{*}{$\mathrm{P}$} & \multirow[b]{2}{*}{$\mathrm{VC}(\%)$} & \multirow[b]{2}{*}{ RMSE } \\
\hline & $\begin{array}{c}100: 0 \\
\text { (Control) }\end{array}$ & $\begin{array}{l}80: 20 \\
(\mathrm{~T} 1)\end{array}$ & $\begin{array}{l}60: 40 \\
(\mathrm{~T} 2)\end{array}$ & $\begin{array}{c}40: 60 \\
\text { (T3) }\end{array}$ & $\begin{array}{c}20: 80 \\
\text { (T4) }\end{array}$ & & & & \\
\hline $\mathrm{BW}^{1}(\mathrm{Kg})$ & 14.50 & 18.36 & 20.48 & 23.59 & 25.86 & 0.67 & $<0.0001$ & 13.53 & 2.889 \\
\hline $\mathrm{BL}^{2}(\mathrm{~cm})$ & 52.02 & 55.42 & 57.61 & 59.48 & 61.24 & 0.64 & $<0.0001$ & 4.23 & 2.445 \\
\hline $\mathrm{HW}^{3}(\mathrm{~cm})$ & 54.62 & 57.24 & 58.53 & 59.93 & 62.32 & 0.64 & $<0.0001$ & 3.32 & 1.993 \\
\hline $\mathrm{HR}^{4}(\mathrm{~cm})$ & 53.66 & 56.70 & 58.06 & 59.53 & 61.74 & 0.64 & $<0.0001$ & 3.52 & 2.051 \\
\hline $\mathrm{CW}^{5}(\mathrm{~cm})$ & 13.58 & 15.18 & 15.23 & 16.81 & 17.75 & 0.69 & $<0.0001$ & 6.14 & 0.975 \\
\hline $\mathrm{RW}^{6}(\mathrm{~cm})$ & 10.80 & 11.70 & 12.53 & 13.41 & 13.77 & 0.70 & $<0.0001$ & 5.72 & 0.720 \\
\hline $\mathrm{HG}^{7}(\mathrm{~cm})$ & 56.94 & 60.06 & 62.63 & 65.85 & 69.07 & 0.77 & $<0.0001$ & 3.70 & 2.352 \\
\hline $\operatorname{BSC}^{8}(0-5)$ & 1.20 & 1.65 & 2.20 & 2.66 & 3.10 & 0.82 & $<0.0001$ & 14.54 & 0.332 \\
\hline $\mathrm{TL}^{9}(\mathrm{~cm})$ & 2.91 & 3.84 & 5.00 & 5.39 & 6.50 & 0.57 & $<0.0001$ & 22.54 & 1.101 \\
\hline $\mathrm{TW}^{10}(\mathrm{~cm})$ & 2.35 & 3.03 & 3.78 & 4.03 & 4.77 & 0.57 & $<0.0001$ & 19.77 & 0.731 \\
\hline $\mathrm{TT}^{11}(\mathrm{~cm})$ & 1.98 & 2.82 & 3.45 & 3.72 & 4.51 & 0.53 & $<0.0001$ & 23.71 & 0.807 \\
\hline $\mathrm{CEL}^{12}(\mathrm{~cm})$ & 1.56 & 1.92 & 2.04 & 2.12 & 2.42 & 0.36 & 0.0006 & 14.96 & 0.299 \\
\hline $\mathrm{CAW}^{13}(\mathrm{~cm})$ & 1.47 & 1.76 & 1.96 & 1.97 & 2.36 & 0.59 & $<0.0001$ & 12.64 & 0.245 \\
\hline $\mathrm{CET}^{14}(\mathrm{~cm})$ & 1.33 & 1.69 & 1.82 & 1.97 & 2.12 & 0.55 & $<0.0001$ & 13.33 & 0.242 \\
\hline $\operatorname{SST}^{15}(\mathrm{~cm})$ & 0.28 & 0.30 & 0.31 & 0.31 & 0.32 & 0.15 & 0.0351 & 12.35 & 0.038 \\
\hline $\mathrm{SP}^{16}(\mathrm{~cm})$ & 12.10 & 14.80 & 17.41 & 19.25 & 22.57 & 0.56 & $<0.0001$ & 18.64 & 3.295 \\
\hline $\mathrm{TV}^{17}\left(\mathrm{~cm}^{3}\right)$ & 26.24 & 68.35 & 137.83 & 147.08 & 243.93 & 0.46 & $<0.0001$ & 60.93 & 81.734 \\
\hline
\end{tabular}

${ }^{1} \hat{\mathrm{Y}}=14.99085+0.13900 \mathrm{x} ;{ }^{2} \hat{\mathrm{Y}}=52.70196+0.11122 \mathrm{x} ;{ }^{3} \hat{\mathrm{Y}}=54.89573+0.09081 \mathrm{x} ;{ }^{4} \hat{\mathrm{Y}}=54.14466+0.09477 \mathrm{x} ;{ }^{5} \hat{\mathrm{Y}}=13.69288+$ $0.05224 \mathrm{x} ;{ }^{6} \hat{\mathrm{Y}}=10.93060+0.03779 \mathrm{x} ;{ }^{7} \hat{\mathrm{Y}}=56.87865+0.15073 \mathrm{x} ;{ }^{8} \hat{\mathrm{Y}}=1.20374+0.2408 \mathrm{x} ;{ }^{9} \hat{\mathrm{Y}}=2.99066+0.04355 \mathrm{x} ;{ }^{10} \hat{\mathrm{Y}}=2.42936$ $+0.02921 \mathrm{x} ;{ }^{11} \hat{\mathrm{Y}}=2.10934+0.02978 \mathrm{x} ;{ }^{12} \hat{\mathrm{Y}}=1.66966+0.00768 \mathrm{x} ;{ }^{13} \hat{\mathrm{Y}}=1.50463+0.01009 \mathrm{x} ;{ }^{1{ }^{1}} \hat{\mathrm{Y}}=1.41726+0.00929 \mathrm{x} ;{ }^{15} \hat{\mathrm{Y}}=$ $0.28612+0.000557 \mathrm{x} ;{ }^{16} \hat{\mathrm{Y}}=12.16701+0.12740 \mathrm{x} ;{ }^{17} \hat{\mathrm{Y}}=21.19151+2.59955 \mathrm{x}$.

Body weights (BW), body condition score (BCS), testis length (TL), testis width (TW), testis thickness (TT), cauda epididymal length (CEL), cauda epididymal width (CAW), cauda epididymal thickness (CET), scrotal perimeter (SP), testicular volume (TV), body length (BL), height at withers (HW), height at rump (HR), chest width (CW), rump width (RW), hearth girth (HG), scrotal skin thickness (SST).

Table 3. Frequency distribution of the shape of the testicles of intensively managed hair sheep lamb.

\begin{tabular}{cccc}
\hline \multirow{2}{*}{ Age in days } & \multicolumn{3}{c}{ Testicular shape } \\
\cline { 2 - 4 } & ovoid-shaped & long ovoid & spherical-shaped \\
\hline 60 & 27.59 & 48.28 & 24.14 \\
74 & 20.69 & 62.07 & 17.24 \\
88 & 41.38 & 48.28 & 10.34 \\
102 & 48.28 & 51.72 & 0.00 \\
\hline
\end{tabular}

The body and testicular-epididymal measurements showed correlations of 0.52 to 0.98 (Table 4). These parameters presented significant positive correlations (BCS x HG, r=0.94; BCS x $\mathrm{BW}, \mathrm{r}=0.92$; HG x BW, r=0.94; HG x BL, 0.89; BL $x$ BCS, $r=0.90)(p<0.005)$. BW and SP have been used at different ages as selection criteria in most of the existing breeding programs, ignoring carcass and other growth traits. Because BW at any age is genetically and positively correlated, selection for BW at a young age will result in larger birth and adult BW (MEYER, 1995; KAPS et al., 1999). 


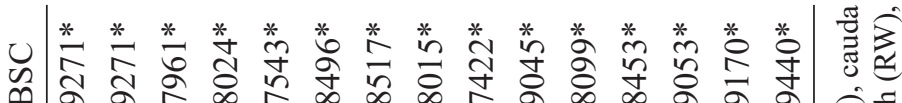

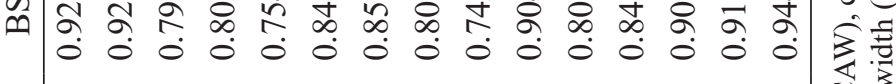

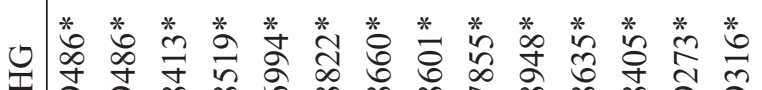

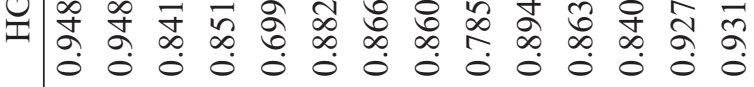

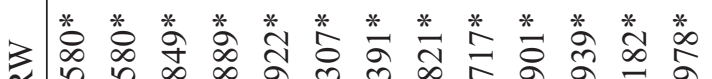

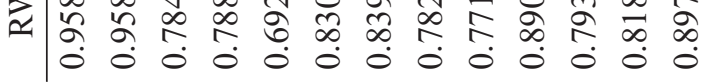

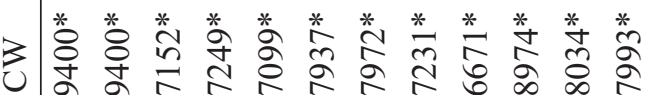

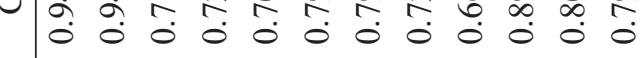

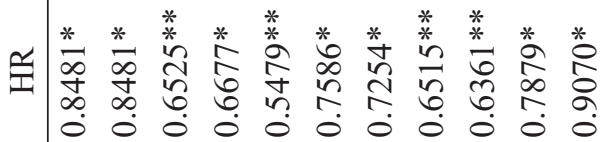

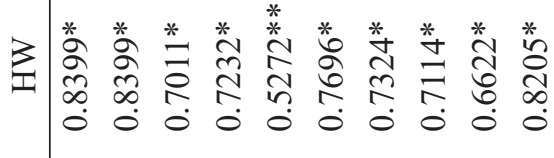

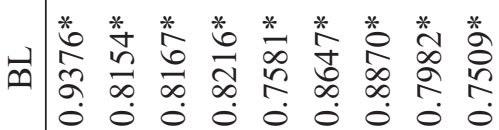

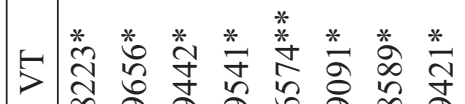

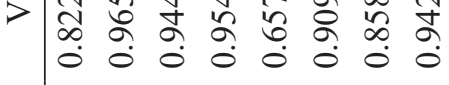

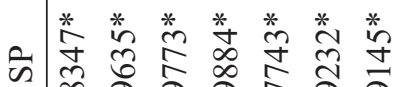

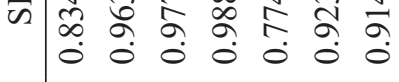

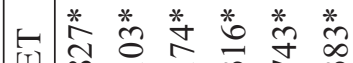

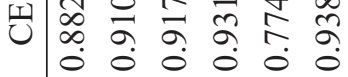

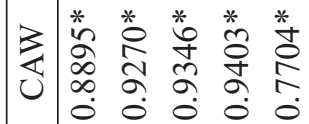

凷

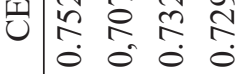

ખ药

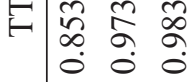

$\begin{array}{lll}* & * \\ \omega & * \\ \infty & 0 \\ \infty & 0 \\ \infty & 0 \\ 0 & 0 \\ * & 0\end{array}$

曰

6

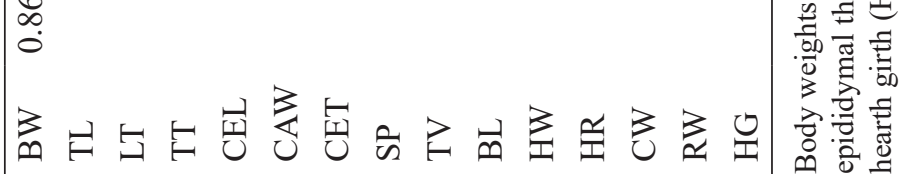


The BW and BCS showed positive high correlations $(\mathrm{P}<0.0001)$ with the length, width, and thickness of the testis and epididymis. The BW also presented high positive correlations to TV $(r=0.82, p<0.0001)$ and SP $(r=0.94, p<0.0001)$. There were moderate positive correlations of $\mathrm{TV}$ with BL, HW, CW and RW ( $\mathrm{r}=0.75,0.66,0.63$, 0.66 and 0.77 , respectively). The BL, CW, RW, $\mathrm{HG}$ and BSC also exhibited high correlations with the testicular-epididymal measurements $(r=0.71$ to 0.94). HW and HR presented a high positive correlation $(\mathrm{p}<0.005)$; however, they were the parameters that showed the lowest correlations with CEL ( $r=0.52$ and 0.54 , respectively). There were high positive correlations $(\mathrm{p}<0.0001)$ among BSC and testicular-epididymal measurements in the present study. In the current study, significant positive correlations were found between $\mathrm{BW}$ and BSC with all body measurements. Positive and significant associations between $\mathrm{BW}$ and several reproductive measurements were observed by Bello and Adama (2012), and Yilmaz et al. (2013), especially with regard to $\mathrm{HG}$ and BL (SOUZA et al., 2009). These results reinforce that BCS, BW and $\mathrm{HG}$ are good parameters to evaluate body development, because they are tools of easy applicability and demonstrate a higher degree of accuracy than the other parameters analyzed.

BW and BCS also showed strong associations with testicular-epididymal measurements. Early studies showed that there are significant positive correlations between testicle measurements and seminal traits in young seven to eight month old rams (ELMAZ et al., 2007). So, this information may be used as criteria for early selection of ram lambs to be used in breeding at relatively young ages (ELMAZ et al., 2007). This result suggests that animals with greater muscle development may be exhibiting the best testicular-epididymal measurements. These results also show the great importance of body measurements and $\mathrm{BW}$ as practical and easy to use methods to choose of ram. In addition, increasing the energetic density intensifies the early development of testicles and epididymis from lambs as also observed in cattle (COULTER; KOZUB, 1984).

The reference values (Table 5) and results of the profile metabolic study in the lambs (Tables 6 and 7) showed interactions between the addition of concentrated feed and blood collection time on total proteins, albumin, urea, cholesterol, phosphorus and magnesium concentrations (Table 6 ). These interactions were not found for globulin and glucose concentrations (Table 7). In the current study, the albumin concentration varied from 32.3 to $50.1 \%$ of the total plasmatic proteins (Table 6). Albumin is the single most common protein found in serum, constituting $35 \%$ to $50 \%$ of total serum protein, and has the function of providing amino acids for the natural turnover of protein in peripheral tissues. In sheep, albumin has a normal half-life of 14.3 days (KANEKO, 2008). This turnover of albumin was verified in treatments 3 and 4, but in the control treatment there was a decrease in albumin concentration; however, the indices were still within the normal range for the species. In ovines, albumin synthesis is calculated to account for a maximum of $17 \%$ of total liver protein synthesis in the fed condition, while this may fall to $8 \%$ during moderate fasts (CONNELL et al., 1997). So, in general, the experimental diets met the protein needs of the lambs during growth because they were elaborated according to recommendations of the NRC (2007). 
Table 5. Reference values of the blood ovine.

\begin{tabular}{lc}
\hline Parameters & Reference values \\
\hline Inorganic Phosphorus $(\mathrm{mg} / \mathrm{dl})$ & 5.0 to 7.3 \\
Magnesium $(\mathrm{mg} / \mathrm{dl})$ & 2.2 to 2.8 \\
Total Cholesterol $(\mathrm{mg} / \mathrm{dl})$ & 52.0 to 76.0 \\
Glucose $(\mathrm{mg} / \mathrm{dl})$ & 50.0 to 80.0 \\
Globulin $(\mathrm{g} / \mathrm{dl})$ & 3.5 to 5.7 \\
Total Proteins $(\mathrm{g} / \mathrm{dl})$ & 6.0 to 7.9 \\
Albumin $(\mathrm{g} / \mathrm{dl})$ & 2.4 to 3.0 \\
Ureia $(\mathrm{mg} / \mathrm{dl})$ & 51.5 to 128.5 \\
\hline
\end{tabular}

Source: adapted by Kaneko (2008)

Plasmatic proteins are synthesized mainly in the liver and skeletal muscle (CONNELL et al., 1997) and are abundant in blood plasma (KANEKO, 2008). Generally, proteins such as albumin undergo continuous synthesis and degradation. In a healthy animal they are in equilibrium, but during disease these can alter (NAVARRE; PUGH, 2002; KANEKO, 2008). In the current study, lambs given treatments 3 and 4 were verified to have hypoproteinemia and hypoalbuminemia in the beginning (Table 6). However, the indices returned to normality as the diets were continued over time. These results suggest recent recovery from a previous illness, like natural infections by Haemonchus contortus and other gastrointestinal nematodes that trigger clinical signs of hypoproteinemia and hypoalbuminemia in lambs (BRICARELLO et al., 2005).

It was verified that in the treatment with $80 \%$ hay and $20 \%$ concentrate (T1) the animals exhibited satisfactory plasmatic urea concentration (Table 6). Blood urea concentration decreased significantly in the control treatment, suggesting inadequate intake of nitrogen by the animals. Some research has shown that exclusive provision of Tifton 85 hay to ovine may result in low retention of nitrogen and high excretion in urine (ATAÍDE JÚNIOR et al., 2000; SANTANA et al., 2014). According to Santana et al. (2014), Tifton 85 grasses, despite showing good energetic value, are not enough to provide full use of the nitrogen available to the ruminant, making it necessary to combine the hay with concentrated food sources that are able to optimize the use of nitrogen. According to Ataíde Júnior et al. (2000), Tifton 85 hay had an excess of nitrogen in relation to energy. Moreover, this forage has good growth in pastures with nitrogen (QUARESMA et al., 2011). Therefore, the diet should have sufficient amounts of highly fermentable energy components when Tifton 85 hay or non-protein nitrogen is used (RANKINS JÚNIOR et al., 2002; SANTANA et al., 2014). Oscillations in urea concentration were observed in other treatments, suggesting that the inclusion of urea in the concentrate given to the Santa Ines lambs was beneficial when Tifton 85 hay was supplied. 


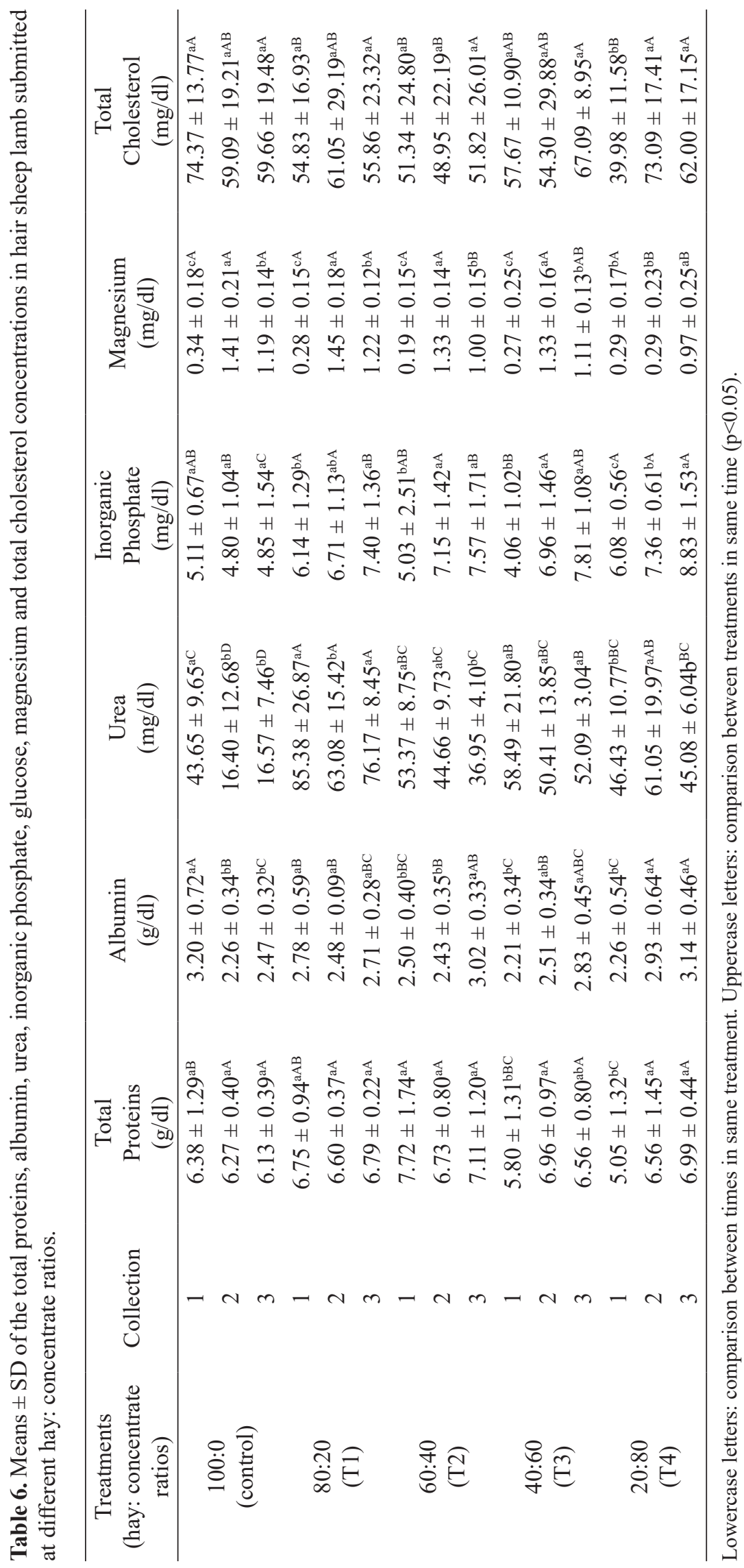


Table 7. Means and SD of the glucose and globulin concentrations in hair sheep lamb submitted at different hay: concentrate ratios.

\begin{tabular}{lccccc}
\hline \multirow{3}{*}{ Parameter } & \multicolumn{5}{c}{ Treatment } \\
\cline { 2 - 6 } & $100: 0$ & $80: 20$ & $60: 40$ & $40: 60$ & $20: 80$ \\
$($ Control $)$ & $(\mathrm{T} 1)$ & $(\mathrm{T} 2)$ & $(\mathrm{T} 3)$ & $(\mathrm{T} 4)$ \\
\hline Glucose $(\mathrm{mg} / \mathrm{dl})$ & $78.01 \pm 9.27$ & $78.32 \pm 10.99$ & $79.24 \pm 23.61$ & $90.32 \pm 21.04$ & $94.11 \pm 20.16$ \\
Globulin $(\mathrm{mg} / \mathrm{dl})$ & $3.61 \pm 1.08$ & $4.05 \pm 0.71$ & $4.53 \pm 1.28$ & $3.92 \pm 1.08$ & $3.42 \pm 1.22$ \\
\hline
\end{tabular}

There was no significant difference between treatments $(\mathrm{p}>0,05)$.

All treatments were verified to induce hypomagnesaemia. Magnesium and phosphorus are considered macro minerals. Martens and Schweigel (2000) verified that the real source of the problem does not come from the cattle but the forages that they ingest. Therefore, an animal's blood magnesium concentration is directly correlated with its diet. In the current experiment low plasmatic magnesium concentrations were observed with all treatments (hypomagnesaemia), showing that Tifton 85 hay does not provide adequate levels of this ion to lambs. According to Martens and Schweigel (2000), there are many nutrients that play a role in magnesium deficiency, especially potassium. Tifton 85 hay has a high potassium concentration in its composition (MATOS et al., 2013). Earlier studies showed that a combination of high nitrogen and potassium levels in forage reduced absorption of magnesium through the ruminant gut (GONZÁLEZ et al., 2000; RANKINS JÚNIOR et al., 2002). So, we recommend the use of a mineral premix containing magnesium in its composition when Tifton 85 hay is provided as food to lambs.

The plasmatic phosphorus concentration was sufficiently high at the end of all treatments, except in the control (Table 6). Calcium and phosphorus are interrelated and are therefore normally discussed together (RANKINS JÚNIOR et al., 2002). Moreover, according to the authors, nearly all of the calcium in the body and most of the phosphorus is found in the skeletal tissues. They say that diets deficient in calcium and phosphorus may delay growth and development in young lambs and kids and predispose them to metabolic bone disease. In this study, calcium was not determined, but plasmatic phosphorus concentration was sufficiently high at the end of all treatments except the control. Sheep and goats fed high proportions of grain or concentrate diets typically need supplemental calcium and little to no additional phosphorus (RANKINS JÚNIOR et al., 2002). On the other hand, when hyperphosphatemia is present in a chemistry profile, it is often accompanied by azotemia (RUSSELL; ROUSSELL, 2007). In this case, the results suggest that the dietary phosphorus level may need to be adjusted, because even normal levels of dietary phosphorus may lead to hyperphosphatemia when Tifton 85 hay is supplied to lambs.

There was light hypocholesterolemia in lambs given $60 \%$ hay and $40 \%$ concentrate (T2) in the diet. This was also observed in $\mathrm{T} 1$ in the first collection. Some differences were verified in plasmatic cholesterol concentration among treatments; however, at the end of the experiments all plasmatic concentrations of this constituent were normal for the species (Table 5). In the control treatment a significant decrease in total cholesterol concentration was verified, but it did not go outside the normal range. Regarding the light hypocholesterolemia observed in some treatments (T2 and initial collection in T4), no explanation was found for these results. Among domestic ruminants, sheep show the lowest blood total cholesterol concentration (KANEKO, 2008). However, earlier 
studies verified that a low plasma cholesterol concentration is also associated with diet of the lambs (CERCI et al., 2011) or diseases such as animal trypanosomosis (WASSINK et al., 1997).

Glucose and globulin were not influenced by the treatments (Table 7). However, in treatments T3 and T4, blood glucose concentrations were above those normal for the species, suggesting excessive intake of amide. According to Topps et al. (1968), propionate remains the principal source of glucose, even when concentrate diets containing large amounts of starch are given. Earlier studies clearly showed that only small amounts reached the abomasum or duodenum, i.e., $6 \%$ of the dietary intake (TOPPS et al., 1968). Furthermore, starch is rapidly fermented into volatile fatty acids, predominantly propionate, in the rumen (FORBES; PROVENZ, 2000). Light hypoglobulinemia was only observed with T4. As there are many types of globulin, it was not easy to determine any conclusion about this metabolite.

\section{Conclusion}

The addition of the concentrated feed positively influenced the lambs' growth. Then, the higher the amount of concentrate fed to lambs, the greater the positive impact on the body, testicular and epididymal measurements. Some body measurements, such as body length, hearth girth, chest width, and rump width as well as body condition score may be used to estimate the development of the testes and epididymis.

Tifton 85 (Cynodon spp) hay should be avoided as the only feed given to lambs because a continuous supply can result in hypomagnesaemia. Thus, the metabolic profile was an important tool to evaluate the nutritional status of hair sheep lambs submitted to different hay: concentrate ratios, because it permitted us to verify that adjustments are necessary in the ratio of concentrate given to lambs when Tifton 85 hay was provided to the animals.

\section{Acknowledgment}

The authors thank Banco do Nordeste for grants to support research.

\section{References}

ABARGHANI, A.; MOSTAFAEI, M.; ALAMISAED, K.; GHANBARI, A.; SAHRAEE, M.; EBRAHIMI, R. Investigation of calcium, phosphorous and magnesium status of grazing sheep in sabalan region, iran. Journal of Agricultural Science and Technology, Tehran v. 15, n. 1, p. 65-76, 2013.

ABBASI, M.-A.; GHAFOURI-KESBI, F. Genetic (Co) variance components for body weight and body measurements in makooei sheep. Asian-Australasian Journal of Animal Sciences, Seoul, v. 24, n. 6, p. 739743, 2011.

ASSOCIATION OF OFFICIAL ANALYTICAL CHEMISTS - AOAC. Official methods of analysis. $15^{\text {th }}$ ed. Virginia: Arlington, 1990. p. 1298.

ATAÍDE JÚNIOR, J. R.; PEREIRA, O. G.; GARCIA, R.; VALADARES FILHO, S. C.; CECON, P. R.; FREITAS, E. V. V. Valor nutritivo do feno de capimtifton 85 (cynodon spp.) em diferentes idades de rebrota, em ovinos. Revista Brasileira de Zootecnia, Viçosa, MG, v. 29, n. 6, p. 2193-2199, 2000.

ATTA, M.; El KHIDIR, O. A. Use of heart girth, wither height and scapuloischial length for prediction of liveweight of Nilotic sheep. Small Ruminant Research, Amsterdam, v. 55, n. 1-3, p. 233-237, 2004.

BABINSZKY, L.; HALAS, V.; VERSTEGEN, M. W. A. Impacts of climate change on animal production and quality of animal food products. In: BLANCO, J.; KHERADMAND, H. (Ed.). Climate change socioeconomic effects. Rijeka: InTech, 2011. p. 165-190.

BAILEY, T. L.; MONKE, D.; HUDSON, R. S.; WOLFE, D. F.; CARSON, R. L.; RIDDELL, M. G. Testicular shape and its relationship to sperm production in mature holstein bulls. Theriogenology, New York, v. 46, n. 5, p. 681-887, 1996.

BELLO, A. A.; ADAMA, T. Z. Studies on body weight and linear body measurements of castrates and noncastrate Savannah Brown goats. Asian Journal of Animal Sciences, New York, v. 6, n. 3, p. 140-146, 2012.

BRICARELLO, P. A.; AMARANTE, A. F. T.; ROCHA, R. A.; CABRAL FILHO, S. L.; HUNTLEY, J. F.; HOUDIJK, J. G. M.; ABDALLA, A. L.; GENNARI, S. M. Influence of dietary protein supply on resistance 
to experimental infections with Haemonchus contortus in Ile de France and Santa Ines lambs. Veterinary Parasitology, New Zealand, v. 134, n. 1-2, p. 99-109, 2005.

CERCI, I. B.; CIFTCI, M.; BAHSI, M.; KILINC, U. Cholesterol and fatty acid composition of lamb serum and offal as affected by alfalfa and concentrate. Veterinarski Archives, Zagreb, v. 81, n. 5, p. 575-584, 2011.

CONNELL, A.; CALDER, A. G.; ANDERSON, S. E.; LOBLEY, G. E. Hepatic monitored protein synthesis in the sheep, effect of intake as by use of stable-isotopelabelled glycine, leucine and phenylalanine. British Journal of Nutrition, Cambridge, v. 77, n. 2, p. 255-271, 1997.

COUlTER, G. H.; KOZUB, G. C. Testicular development, epididymal sperm reserves and seminal quality in two-year-old Hereford and Angus bulls: effects of two levels of dietary energy. Journal of Animal Science, Champaign, v. 59, n. 2, p. 432-340, 1984.

DAVID, D. B.; POLI, C. H. E. C.; AZEVEDO, E. B.; FERNANDES, M. A. M.; CARVALHO, P. C. F.; JOCHIMS, F.; PIMENTEL, C. M. M. Potential response to supplementation of ewe lambs grazing natural pastures over winter. Small Ruminant Research, Amsterdam, v. 105, n. 1-3, p. 22-28, 2012.

DUGUMA, G.; ClOETE, S. W. P.; SCHOEMAN, S. J.; JORDAAN, G. F. Genetic parameters of testicular measurements in Merino rams and the influence of scrotal circumference on total flock fertility. South African Journal of Animal Science, Petroria, v. 32, n. 1-3, p. 76-82, 2002.

ELMAZ, O.; CIRIT, Ü.; DEMIR, H. Relationship of testicular development with age, body weight, semen characteristics and testosterone in Kivircik ram lambs. South African Journal of Animal Science, Petroria, v. 37, n. 4, p. 269-274, 2007.

FORBES, J. M.; PROVENZA, F. D. Integration of learning and metabolic signals into a theory of dietary choice and food intake. In: CRONJÉ, P.B. (Ed.). Ruminant physiology, digestion, metabolism, growth and reproduction. London: CABI Publishing Cambridge, 2000. p. 3-19.

GATTANI, A.; GUPTA, K. K.; JOSHI, G.; GUPTA, S. R. Metabolic profile of foot and mouth disease stressed sheep in semi arid region. Journal of Stress Physiology \& Biochemistry, Moscow, v. 7, n. 2, p. 148-153, 2011.

GONZÁLEZ, F. H. D. Indicadores sanguíneos do metabolismo mineral em ruminantes. In: GONZÁLEZ, F. H. D.; BARCELLOS, J. O.; OSPINA, H.; RIBEIRO, L. A. (Ed.). Perfil metabólico em ruminantes: seu uso em nutrição e doenças nutricionais. Porto Alegre: Gráfica da Universidade Federal do Rio Grande do Sul, 2000. p. 3151.

GONZÁlEZ, F. H. D.; SCHEFFER, J. S. F. Perfil sanguíneo: ferramenta de análise clínica, metabólica e nutricional. In: SIMPÓSIO DE PATOLOGIA CLÍNICA VETERINÁRIA DA REGIÃO SUL DO BRASIL, 1., 2003, Porto Alegre. Anais... Porto Alegre: Gráfica da Universidade Federal do Rio Grande do Sul, 2003. p. 7389.

HALL, M. B. Calculation of non-structural carbohydrate content of feeds that contain non-protein nitrogen. Gainesville: University of Florida, 2000. p. A-25. (Bulletin, 339).

KANEKO, J. J. Carbohydrate metabolism and its diseases. In: KANEKO, J. J.; HARVEY, J. W.; BRUSS, M. L. (Ed.). Clinical biochemistry of domestic animals. $6^{\text {th }}$ ed. San Diego, California: Academic Press, 2008. p. 45-80.

KAPS, M.; HERRING, W.O.; LAMBERSON, W. R. Genetic and environmental parameters for mature weight in Angus cattle. Journal Animal Science Champaign, v. 77, n. 3, p. 569-574, 1999.

INSTITUTO BRASILEIRO DE GEOGRAFIA E ESTATISTICA - IBGE. Produção da pecuária municipal. Rio de Janeiro: IBGE, v. 39, p. 1-63, 2011.

LOUVANDINI, H.; MCMANUS, C.; MARTINS, R. D. Características biométricas testiculares em carneiros Santa Inês submetidos a diferentes regimes de suplementação proteica e tratamentos anti-helmínticos. Ciência Animal Brasileira, Goiânia, v. 9, n. 3, p. 638647, 2008.

MARTENS, H.; SCHWEIGEL, M. Pathophysiology of grass tetany and other hypomagnesemias. Implications for clinical management. Veterinary Clinical North America Food Animal Practice, Amsterdam, v. 16, n. 2, p. 339-368, 2000.

MATOS, A. T.; SILVA, D. F.; LO MONACO, P. A. V.; PEREIRA, O. G. Produtividade e composição química do capim-tifton 85 submetido a diferentes taxas de aplicação do percolado de resíduo sólido urbano. Engenharia Agrícola, Jaboticabal, v. 33, n. 1, p. 188-200, 2013.

MEYER, K. Estimates of genetic parameters for mature weight of Australian beef cows and its relationships to early growth and skeletal measures. Livestock Production Science, Foulum, v. 44, n. 2, p. 125-137, 1995.

MUHAMMAD, N.; TUKUR, H. M. Assessment of growth rate of Uda sheep fed diets containting varying energy levels using live morphometry. Journal of Animal Genetics Research, New York, v. 1, n. 1, p. 1-5, 2013. 
NATIONAL RESEARCH COUNCIL - NRC. Nutrient requirements of small ruminants: sheep, goats, cervids, and New World Camelids. $6^{\text {th }}$ rev. ed. Washington, DC: National Academy Press, 2007. 384 p.

NAVARRE, C. B.; PUGH, D. G. Diseases of the gastrointestinal system. In: PUGH, D.G. (Ed.). Sheep \& goat medicine. $2^{\text {th }}$ ed. Amesterdam: Elsevier, 2002. p. 69105.

OWENS, F. N.; DUBESKI, P.; HANSON, C. F. Factors that alter the growth and development of ruminants. Journal of Animal Science, Champaign, v. 71, n. 11, p. 3138-3150, 1993.

PAIVA, S. R.; SILVÉRIO, V. C.; PAIVA, D. A. F.; MCMANUS, C. M.; EGITO, A. A.; FARIA, D. A.; MARIANTE, A. S.; CASTRO, S. T. R.; ALBUQUERQUE, M. S. M.; DERGAM, J. A. Origin of the main locally adapted sheep breeds of Brazil, A RFLPPCR molecular analysis. Archives Zootechny, Cordoba, v. 54, n. 208, p. 395-399, 2005.

QUARESMA, J. P. S.; ALMEIDA, R. G.; ABREU, J. G.; CABRAL, L. S.; OLIVEIRA, M. A.; CARVALHO, D. M. G. Produção e composição bromatológica do capimtifton 85 (Cynodon spp.) submetido a doses de nitrogênio. Acta Scientiarum Animal Sciences, Maringá, v. 33, n. 2, p. 145-150, 2011.

RANKINS JÚNIOR, D. L.; RUFFIN, D. C.; PUGH, D. G. Feeding and nutrition. In: PUGH, D. G. (Ed.). Sheep $\&$ goat medicine. $2^{\text {th }}$ ed. Amesterdam: Elsevier, 2002. p. 19-60.

RUSSEL, A. J. F.; DONEY, J. M.; GUNN, R. G. Subjective assessment of fat in live sheep. Journal Agricultural Science, Cambridge, v. 72, n. 3, p. 451-454, 1969.

RUSSELL, K. E.; ROUSSEL, A. J. Evaluation of the ruminant serum chemistry profile. Veterinary Clinics of North America Food Animal Practice, Amsterdam, v. 23, n. 3, p. 403-426, 2007.

SANTANA, Y. A. G.; ALVES, A. A.; OLIVEIRA, M. E.; MOREIRA FILHO, M. A.; CERQUEIRA NETO, C. F. Nutritive value of sheep diets made up of hay from Tifton 85 grass and leucaena. Revista Ciência Agronômica, Fortaleza, v. 45, n. 2, p. 387-392, 2014.
STATISTICAL ANALYSIS SYSTEM - SAS. System for windows. Release 9.1 (TS1M3). Cary: SAS Institute, $2003.78 \mathrm{p}$.

SOUZA, S.; LEAL, A.; BARIONI, C.; MATOS, A.; MORAIS, J.; ARAÚJO, M.; NETO, O.; SANTOS, A.; COSTA, R. Utilização de medidas biométricas para estimar peso vivo em ovinos. Archivos Latinoamericana de Producción Animal, Maracaibo, v. 17, n. 3, p. 61-66, 2009.

TOPPS, J. H.; KAY, R. N. B.; GOODALL, E. D. Digestion of concentrate and of hay diets in the stomach and intestine of ruminants. British Journal of Nutrition, Cambridge, v. 22, n. 2, p. 261-280, 1968.

WASSINK, G. J.; FISHWICK, G.; PARKINS, J. J.; GILL, M.; ROMNEY, D. L.; RICHARD, D.; HOLMES, P. H. The patho-physiology of Trypanosoma congolense in Scottish Blackface sheep, influence of diet on digestive function. Animal Science, Cambridge, v. 64, n. 1, p. 127 137, 1997.

WEISS, W. P. Energy prediction equations for ruminant feeds. In: CORNELL NUTRITION CONFERENCE FOR FEED MANUFACTURERS, 61., 1999, Ithaca. Proceedings... Ithaca: Cornell University, 1999. p. 176185.

YADAV, D. K.; JAIN, A.; KULKARNI, V. S.; GOVINDAIAH, M. G.; ASWATHNARAYAN, T.; SADANA, D. K. Classification of four ovine breeds of southern peninsular zone of India, morphometric study using classical discriminant function analysis. SpringerPlus, Heidelberg, v. 2, n. 1, p. 1-8, 2013.

YAKUBU, A.; IBRAHIM, I. A. Multivariate analysis of morphostructural characteristics in Nigerian indigenous sheep. Italian Journal of Animal Science, Pavia, v. 10, n. 2, p. 83-86, 2011.

YILMAZ, O.; CEMAL, I.; KARACA, O. Estimation of mature live weight using somebody measurements in Karya sheep. Tropical Animal Health and Production, Heidelberg, v. 45, n. 2, p. 397-403, 2013. 